Jurnal Magister Hukum Ekonomi Syariah

Vol 5, No 1 tahun 2021 hal 92-105

EISSN: 2614-865X PISSN: 2598-5043

Website: http://journal.um-surabaya.ac.id/index.php/JE/index

\title{
KONSEP QIYAS AKAD MUDHARABAH TERHADAP AKAD MUSAQAH
}

\author{
M. Lathoif Ghazali ${ }^{1}$ \\ Yudi Amirul Aji Amanda ${ }^{2}$ \\ ${ }^{1}$ Universitas Islam Negeri Sunan Ampel Surabaya \\ e-mail: muhammadlathoif@gmail.com \\ ${ }^{2}$ Universitas Negeri Sunan Ampel Surabaya \\ e-mail : yudiamirul@gmail.com
}

\begin{abstract}
Research aims to understand the concept of qiyas in mudharabah divorce .This research result indicates that mudharabah divorce with musaqah illah have in common, in common can be viewed from the side of understanding, in the manner of the agreement and the cancellation of requirements as the requirements sighat in both the divorce requiring the sighat (ijab and qabul), and there are also requirements and do not all requirements used same it is just in object the division of the gaining of it is that would differ, if not of capital mudharabah used in the form of money, musaqah in the form of a garden, mudharabah used in divorce and financial institution musaqah in use in agribusinesses. In nullification only two point according to researchers under the same one of both the parties that died and things that block the annulment of (crazy or murtad). The practice of akkad mudharabah is as ashl then al-musaqah is as far'u, after we had put together in the same evidence is cooperation between / owners or those with capital manager / the best of garden against the power to keep the business going and then within the division of the gaining of it is divorce agreement has been agreed upon at the beginning. So with this, and not even go near mudharabah musaqah in in business activities.
\end{abstract}

Keywords : Qiyas, Illat, Mudharabah, Musaqah

\section{A. PENDAHULUAN}

Didalam kehidupan sehari-hari umat Islam mempunyai peraturan untuk mengatur seluruh aktivitas serta mempunyai batasan tertentu untuk melaksanakannya, dalam batasan hukum yang berlandaskan Alqur'an dan As-Sunnah.

Terdapat beberapa peristiwa yang belum jelas hukumnya, karena didalam AlQuran dan sunnah belum menjumpai secara jelas hukumnya. Maka dari itu diperlukan sebuah metode yang dapat memperjelas serta menyingkap meskipun suatu hukum yang sudah ditentukan.
Pada zaman Rasulullah SAW masalahmasalah yang dihadapi dan muncul bisa teratasi karena bertanya secara langsung kepada Rasulullah SAW, akan tetapi pada masa sekarang jika terdapat masalah/problem yang muncul dan bermacam-macam masalah yang belum ditemukan dalam Al-Quran dan Sunnah. Setelah itu para ulama melakukan suatu pendekatan dengan cara berijtihad yaitu dengan menggunakan metode qiyas.

Qiyas merupakan metode menggali (istinbat) yang hukumnya sangat popular di kalangan mazhab syafii. Mazhab Syafii meletakkan qiyas pada bagian keempat 
sesudah al-Qur'an, hadis, dan ijmak. Imam Syafii. ${ }^{1}$ Imam Syafii memakai qiyas untuk salah satunya jalur dalam menggali hukum, serta dia berkata jika yang dinamakan ijtihad merupakan qiyas adalah qiyas. Imam Syafii menjelaskan bahwa "qiyas" dan "ijtihad" merpuakan dua kata yang memiliki arti yang sama. $^{2}$

Jika melihat dari beberapa akad-akad di ekonomi Islam, salah satunya akad mudharabah yang dapat diqiyaskan dengan Al-Musaqah yang dimana sama-sama memberikan modal dan yang diberikan mengelola modal tersebut dan keuntungannnya dibagi dengan porsi yang sudah disepakati sebelumnya. Akan tetapi walaupun model perjanjiannya yang diberikan sama nampun terdapat perbedaan dari sisi objeknya. Mudharabah sering di aplikasikan pada lembaga keuangan syariah dan Al-Musaqah didalam kerja sama pertanian.

Pada hakikatnya syariat Islam melakukan aktivitas dalam bidang muamalah yang hanya memberikan prinsip dan petunjuk dengan sifat yang mendasar dan umum saja. Namun jika melalui qiyas dan ijtihad maka hal tersebut dalam menjadi detail, rinci dan teknis yang tidak diatur, proses ijtihad dan pengqiyasan ini diserahkan kepada manusia dalam pengkajiannya. ${ }^{3}$

Di sini, penulis ingin memberikan pemaparan mengenai konsep qiyas di dalam akad Mudharabah.

\section{B. METODE PENELITIAN}

Penelitian ini merupakan penelitian kepustakaan (library research). Penelitian

\footnotetext{
${ }^{1}$ Ahmad Masfuful Fuad, "Qiyas Sebagai Salah Satu Metode Istinbāt Al-Hukm", UIN Sunan Kali Jaga, Mazahib,Vo.1, No.1 (2016). 43.

${ }^{2}$ Ibid. 43.

${ }^{3}$ Anni Muslimah Purnamawati, "Konsep Qiyas dalam Transaksi Ekonomi Money Changer", Sekolah Tinggi Agama Islam Negeri Pamekasan, Ekomadania Volume 1. Nomor 1. (Juli 2017), 118.
}

kepustakaan dilakukan dengan cara mengkaji literatur berdasarkan permasalahan. Dalam pengumpulan data (data primer dan data sekunder) yang berkaitan dengan objek penelitian, penulis menggunakan metode kepustakaan. Data tersebut berasal dari buku-buku terkait penelitian, hasil penelitian, jurnal dan dokumen lainnya. Library research adalah penelitian yang dilakukan dengan mengumpulkan berbagai macam dokumen yang berkaitan dengan topik penelitian. Penelitian dilakukan melalui pengumpulan jurnal dan pengumpulan data tentang konsep "Qiyas" dalam Perjanjian Mudharabah. Inilah yang menjadi fokus penelitian ini, sehingga penelitian ini sangat kuat.

\section{Gambaran Umum}

\section{Pengertian Qiyas}

Qiyas istilah bahasa merupakan suatu pengukuran atau penyamaan sesuatu dengan sejenisnya (disamakan). ${ }^{4}$ Qiyas di artikan oleh Imam syafii sebagai cara pencarian (ketatapan hukum) dengan berlandaskan dalil-dalil yang mengarah pada sesuatu yang pernah di dapatkan/diinformasikan didalam Al-quran dan Hadist. ${ }^{5}$

Lalu dalam terminology qiyas mempunyai beberapa dari hasil definisi tokoh ushul fiqh, walaupun menggunakan redaksi yang tidak sama, tetapi dalam pengertian dengan kandungan yang sama. Diantaranya oleh shadr asy Syariah (747 H/1346 M, tokoh ushul fiqih Hanafi) yaitu :

"memberlakukan hukum asal kepada hukum furu' disebabkan

\footnotetext{
${ }^{4}$ Rahmat Syafii, "ilmu Ushul Fiqh", (Bandung: Pustaka Setia, 2010). 86.

${ }^{5}$ Andi Ahriana Astuti Bahar, "Tinjauan Hukum Islam Terhadap Pembelian Barang Koleksi di Kelurahan Tamarunang Kecamatan Somba Opu Kabupaten Gowa (Studi Perbandingan Imam Abu Hanifa dan Imam Syafi'i)", Universitas Islam Negeri Alauddin, Vol. 1, No. 3, (2020). 598.
} 
kesatuan illah yang tidak dapat dicapai melalui hanya dengan pendekatan bahasa". ${ }^{[6]}$

Yang dimaksud illah disini adalah pada satu nas yang sama dengan illah pada kasus yang masih dihadapi oleh ahli ushul fiqh, dan sebab dalam kesatuan illah ini, bahwa hukum yang masih diatasi akan di samakan dengan hukum yang ditentukan oleh nasnya.

Lalu menurut para ulama Syafi'iyyah mendefinisikan qiyas dengan:

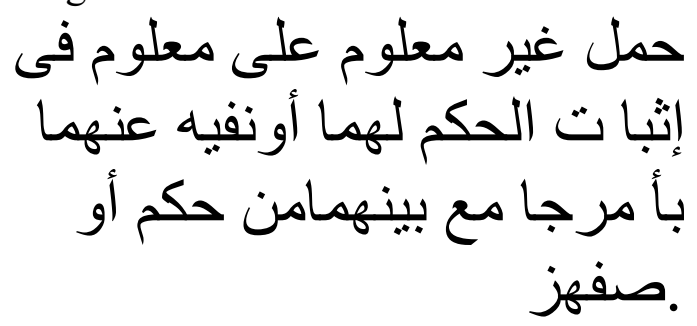

Artinya :

"membawa (hukum) yang (belum) diketahui kepada (hukum) yang diketahui dalam rangka menetapkan hukum bagi keduanya, atau meniadakan hukum bagi keduanya, disebabkan sesuatu yang menyatukan keduanya, baik hukum maupun sifat."

Menurut Saifuddin Al-Amidi qiyas yaitu:

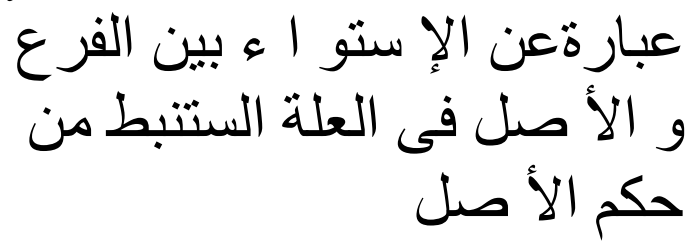

Artinya :

"mempersamakan illah yang ada pada furu' dengan illah yang ada pada ashal yang diistinbatkan dari hukum ashal."

Menurut Wahbah al-Zuhaili qiyas yaitu :

${ }^{6}$ Ratu Haika, "Konsep Qiyas Dan Ad Dalil Dalam Istinbat Hukum Ibn Hazm", STAIN Samarinda, Fenomena, Vol.4, No.1, (2012). 94.

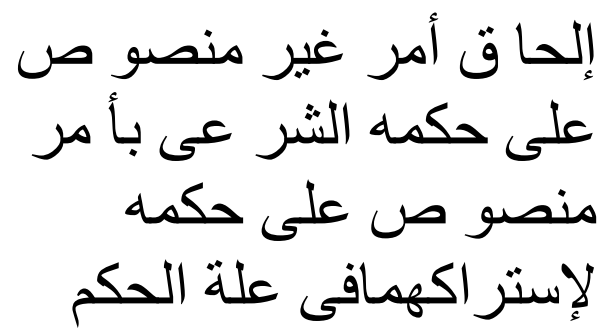

Artinya :

"menyatukan Sesutu yang tidak disebutkan hukumnya dalam nas dengan sesuatu yang disebutkan hukumnya oleh nas, disebabkan kesatuan illah hukum antara keduanya"

Walaupun adanya perbedaan definisi dalam redaksinya para pakar ushul fiqih kontemporer dan klasik tentang qiyas, akan tetapi mereka tetap akan sependapat dalam menyatakan bahwa dalam penetapan suatu hukum dengan metode qiyas bukanlah menetapkan hukumnya dari awal (itsbat al-hukm wa Inysa'uhu), melainkan Cuma menyingkapkan serta memaparkan hukum yang terselip pada permasalahan/sesuatu problem yang belum jelas hukumnya. ${ }^{7}$

Dalam kaidah Qiyas perihal tersebut dapat dimaksud para mujtahid telah mengembalikan syarat hukum kepada sumbernya AlQuran serta hadits, sebab suat hukum didalam Islam, adakalanya bertabiat implisit - analogik yang ada dalam nash tersebut. perihal tersebut Imam Syafii berkata tentang qiyas jika:" Tiap kejadian tentu terselip kepastian hukum serta umat islam harus melaksanakannya. Hendak namun bila tidak terdapat syarat hukumnya yang tentu, hingga wajib dicari pendekatan yang legal, ialah dengan ijtihad. Serta ijtihad itu merupakan Qiyas.”

Maka dari itu hukum Islam terkadang bisa diketahui dengan bunyi nash, yaitu hukum secara jelas tersurat didalam AlQuran dan hadits, dan juga

\footnotetext{
${ }^{7} \mathrm{Ibid}, 94$.
} 
sesekali untuk digali melalui ketelitian memahami kandugan dan makna nash. Demikian hal itu didapatkan melalui pendekatan qiyas.

Begitu pula di jelaskan, Kalau qiyas merupakan mempertemukan sesuatu perihal yang tidak ada nash hukumnya dengan perihal lain yang ada nas hukumnya, karena terdapat persamaan illat hukum. Hingga dengan begitu qiyas ialah perihal yang fitri serta tidak berubah-ubah bersumber pada penalaran yang jelas, sebab asas qiyas ialah penghubung dua permasalahan secara analogy yang bersumber pada persamaan watak serta karena yang membentuknya. Bila menciptakan titik persamaan antara karena dengan watak secara pendekatan analogis antara dua permasalahan tersebut, dengan demikian konsekuensinya wajib sama dengan hukum yang ditetapkan. ${ }^{8}$

\section{Rukun dan Syarat Qiyas}

Qiyas dianggap akan menjadi sah apabila rukun dan syaratnya lengkap. Ulama ushul fiqh menyepakati bahwa yang menjadi ruku qiyas ada empat :

a. Ashal (pokok tempat mengqiyaskan suatu), ialah peristiwa yang memiliki nash buat dijadikan tempat dalam mengqiyaskan sesuatu kejadian. Perihal ini didasarkan pada penafsiran ashl bagi fuqaha, sebaliknya ashl bagi teolog ialah sesuatu nassyara' yang menampilkan syarat hukum dengan kata lain, sesuatu nash yang jadi dasar hukum. Ashl diucap pula naqis alaih (jadi tempat mengqiyaskan) mahmulalaih (tempat buat menyamakan) ataupun musyabbah bih( tempat buat menyerupakan).

\footnotetext{
${ }^{8}$ Ahmad Masfuful Fuad, "Qiyas Sebagai Salah Satu
} Metode Istinbāt Al-Hukm".....43-44.

\section{Dalam rukun qiyas yang pertama terdapat beberapa persyaratan yang ditetapkan oleh} ulama diantaranya :

1) Al-ashl tidak mansukh maksudnya, syara' hukum yang akan dijadikan untuk sumber pengqiyasan itu pada masa Rasulullah SAW masih tetap berlaku. Jika ketentuan hukumnya sudah dihapuskan, maka ia tidak bisa menjadi alashl .

2) Syara' hukum ini sangatlah jelas dan mutlak persyaratannya, karena ketentuan hukumnya hendak ditemukan melalui qiyas yaitu syara' hukum bukan ketentuan hukum yang lainnya. Oleh sebab itu, maka mestilah ia yang berupa syara' hukum.

3) Tidaklah suatu hukum yang dikecualikan. apabila al-ashl itu adalah pengecualian, maka hal tersebut tidak bisa dijadikan sebagai wadah qiyas. Misalkan penetapan sunnah berpuasa, bahwa puasa dikarenakan lupa tidaklah batal. Dalam ketentuan tersebut tidak bisa dijadikan sebagai ashl alqiyas untuk ditetapkannya bahwa tidak batalnya berpuasa orang yang berbuka puasa secara terpaksa.

b. Cabang (far’u) merupakan kejadian yang tidak mempunyai suatu nashnya. Far'u tersebut yang dikehendaki agar disamakan hukum dengan al-ashl. Hal itu juga bisa disebut dengan maqis (yang dianalogikan) serta musyabbah (yang diserupakan). Beberapa ulama menyebutkan tentang syarat terhadap rukun far'u antara lain : 
1) Sebelum kejadian tersebut diqiyaskan tidak ada nash lainnya yang menentukan hukumnya. Apabila terdapat nash yang ditentukan terlebih dahulu hukumnya, tentulah tidak boleh dan dilakukan qiyas terhadapnya.

2) Illat yang ada didalam al-ashl memiliki kesamaan dengan yang ada didalam al-far'u.

3) Tidak adanya dalil qat iy yang kandungannya bahwa dengan al-far'u.

4) Hukum didalam al-ashl sifatnya sama dengan hukum didalam al-far'u.

c. Dalam hukum ashl, yakni suatu hukum yang berada dalam suatu permasalahan yang dimana ketentuan hukumnya ditetapkan nash tertentu, baik dari al-Quran maupun sunnah. Terdapat beberapa rukun di hukum ashl, para ulama mengemukakan, syarat-syaratnya ialah sebagai berikut :

1) Hukum ashl merupakan hukum syara'dan bukanlah yang berhubungan dengan hukum lughawiyyat, adiyyat dan aqliyyat. Syarat sebenarnya hampir tidak perlu disebutkan, karena hendak untuk diketahui hukumnya yaitu hukum syara'.

2) Illah hukum itu bisa ditemukan, bukan suatu hukum yang tidak bisa dipahami dari illahnya.

3) Hukum ashl tidak termsuk dalam suatu kelompok yang menjadi khushushiyyah Rasulullah.

4) Hukum ashl masih digunakan dan berlaku sejak wafatnya Rasulullah SAW, bukan suatu ketentuan hukum yang mansukh (dibatalkan). Contoh

$$
\begin{array}{ll}
\text { dari unsur hukum ashl, } & \text { ansur } \\
\text { dikaitkan dengan } & \text { unsur } \\
\text { pertama dan kedua } & \text { ialah, } \\
\text { hukum haramnya } & \text { bunga } \\
\text { (interest) dan khamr. } &
\end{array}
$$

d. Illah, sifat yang dimiliki ashl. Adanya illah yang terdapat pada ashl membuat ashl mempunyai suatu hukum. Dengan illah itu juga, terdapat cabang, sehingga hukum pada cabang itu disamakan dengan hukum ashl. Untuk bisa dipandang sah sebagai illah para ulama menetapkan beberapa syarat suatu illah hukum diantaranya :

1) Zhahir, merupakan 'illah yang seharusnya suatu sifat nyata dan jelas serta bisa dibedakan dan dilihat dengan dari sifat dan keadaan lainnya. Suatu sifat yang tidaklah nyata (bathin) lalu tidak bisa menjadi 'illah hukum. sifat 'illah yang nyata itu, seperti: sifat yang pandai/cerdas (ar-rusyd) dalam penentuan kepintaran untuk memberikan harta dari wali kepada orang dibawah perwaliannya.

2) 'Illah diharuskan mengandung hikmah yang sama dengan tujuan serta kaitan hukum. Dalam hal tersebut, tujuan dari hukum adalah jelas, yakni kemaslahatan mukallaf di dunia dan di akhirat.

3) Mundabitah, adalah 'illah pastilah sesuatu yang jelas batasnya dan bisa diukur. Jika ia bisa dikacaukan dengan sifat yang lainnya dan tidak terukur, maka ia tidaklah sah dijadikan sebagai 'illah.

4) Mula'im wa' munasib, adalah bentuk 'illah yang harus mempunyai hubungan dan 
mempunyai kelayakan yang sama diantara sifat dan hukum yang dilihat dengan 'illah. Apabila diantara sifat dan hukum yang dilihat sebagai 'illah tidak berhubungan dan tidak mempunyai kepantasan, maka tidak bisa ditetapkan sebagai 'illah.

5) Muta'addiyah, Merupakan wujud karakter yang tidak hanya ada dalam peristiwa yang termasuk dalam teks hukum, tetapi juga dalam peristiwa lain yang membutuhkan hukum. Jika illah dibatasi, yang ada hanya al-ashl (peristiwa hukum yang mengandung klausa teks, yang tidak ada dalam peristiwa hukum tanpa teks tetapi tidak ada teks hukum ('illah qashirah), dan kemudian tidak sah sebagai "illah".

Jika dihubungkan dengan unsur qiyas sebelumnya, Rukun tingkat keempat adalah inti sari sifat yang memabukkan dari khamr. Ciri-ciri ini bisa diukur, benar dan tepat, dan bisa dijadikan hikmah, melarang penggunaan khamr / alkohol dan minuman memabukkan lainnya. ${ }^{9}$

cara menentukan illat qiyas diantaranya :

a. Yang menunjukkan dari nasnya, karena dalam hal seperti ini nas itulah yang menunjukkan bahwa suatu sifat adalah illat hukum dari suatu peristiwa.

b. Yang menunjukkan dari ijma nya, artinya bahwa illat sudah ditetapkan dengan ijma`.

${ }^{9}$ H Darmawan, "Ushul Fiqh" (Surabaya : Revka Prima Media, 2020). 88-90. c. Cara menggunakan metode penelitian/ijtihad, maksudnya illat sendiri bisa diketahui melalui penelitian dengan diketahui oleh empat cara diantaranya munasabah, tahqiq al-manath, tanhiq al-manath dan al sabru wal al-taqsim. ${ }^{10}$

\section{Kehujjahan Qiyas}

Ulama Jumhur beranggapan qiyas itu menjadi hujjah syariah (sumber hukum syariah) untuk hukum amal perbuatan manusia berada pada tingkatan keempat dari dalil-dalil syariah. Dengan hal tersebut apabila suatu peristiwa tidak terdapat hokum yang ditetapkan dari suatu nash atau ijma' serta memiliki persamaan illat dengan kejadian yang mempunyai nash. Golongan ini, oleh para pakar ushl fiqh disebut dengan Mutsbitul Qiyas. (kelompok yang menetapkan kehujjahan dari qiyas).

Ulama Nizhamiyah, Zhahiriyah dan sebagian ulama aliran Syi'ah beranggapan Qiyas bukannlah hujjah syariah yang bisa untuk menetapkan hukum. Lalu mereka kemudian dikenal dengan sebutan Nafatul Qiyas (kelompok yang mengingkari kehujjahan dari qiyas).

Ulama jumhur memberikan suatu alasan dalam menetapkan kehujjahan qiyas terdiri dari Al-Qur'an, as-Sunnah, pendapat dan perbuatan dari para sahabat serta logika.

a. Dalil Al-Qur'an

Mereka menggunakan ayat AlQuran sebagai suatu alasan dalam menetapkan kehujjahan qiyas, adalah pada firman Allah.

\footnotetext{
${ }^{10}$ Fathurrahman Azhari, "Qiyas Sebuah Metode Penggalian Hukum Islam", Jurnal Hukum dan Pemikiran, UIN Antasari, Vol 13, No 1 (2013), 34.
} 
Artinya :

"Hai orang-orang yang beriman, taatilah Allah dan taatilah Rasul (Nya), dan ulil amri di antara kamu. kemudian jika kamu berlainan Pendapat tentang sesuatu, Maka kembalikanlah ia kepada Allah (Al Quran) dan Rasul (sunnahnya), jika kamu benarbenar beriman kepada Allah dan hari kemudian. yang demikian itu lebih utama (bagimu) dan lebih baik akibatnya." (Surat An-Nisa : 59).

Dalam ayat tersebut menjelaskan bahwa Allah memerintahkan untuk semua orang mukmin, jika terdapat perselisihan pendapat dalam hal hukum suatu kejadian yang masuk didalam AlQuran, assunnah dan suatu keputusan dari orang yang diberikan kekuasaan tidak ada, lalu hendaklah dikembalikan kepada Allah dan Rasul-Nya. Oleh sebab itu menyamakan suatu hukum peristiwa yang tidak ada nashnya, karena adanya illat hukum yang sama merupakan hal yang termasuk mengembalikan suatu kejadian yang tidak memiliki nash, dan kepada Allah serta Rasul-Nya. Karena hal tersebut brarti mengikuti hukum Allah dan RasulNya. ${ }^{11}$

b. Dalil Sunnah

Dalil-dalil as-Sunnah itu antara lain adala sabda Rasulullah SAW dalam membai'at Muadz bin Jabal sebagai walikota di Yaman, katanya :

"Bagaimanakah kamu memutusi perkara bila dikemukakan masalah kepadamu? Jawab Muadz, aku memutuskan dengan Kitabullah.

11 H Darmawan, "Ushul Fiqh".....84.
Maka jika masalah itu tidak terdapat di dalam kitab Allah? Tanya Rasul selanjutnya. Maka dengan Sunnah Rasulullah SAW, jawabannya. Kemudian Rasul menanyakannya lebih lanjut. Jika masalah itu tidak terdapat dalam sunnah Rasulullah? Aku berijtihad dengan pendapatku dan berusaha dengan segenap tenaga, katanya. Lalu Muadz meneruskan ceritanya, ujarnya: Rasulullah SAW lalu menepuk dadanya dan seraya bersabda: Segala puji milik Allah yang telah membimbing utusan Rasulullah karena telah membuat keridhoan Allah dan Rasul-Nya."

Hadits ini menerangkan pengakuan Rasulullah SAW terhadap bolehnya berijtihad, bila tidak dapat nas dari al-Qur'an maupun dari al-Hadith, ijtihad itu tidak lain dari usaha yang sungguhsungguh untuk mencapai suatu ketetapan hukum. Sedangkan usaha-usaha itu dapat juga dijalankan dengan menganalogikan peristiwa yang tidak ada nashnya kepada peristiwa yang ada nashnya dengan memperhatikan persamaan illatnya (ini disebut mengqiyaskan). ${ }^{12}$

c. Dalil Logika

Analisis jelas dan logis yang mereka gunakan dalam menetapkan kehujjahan qiyas yaitu sebagai berikut : ${ }^{13}$

1) Allah Ta'ala tidak memutuskan hukum untuk hambaNya, apabila tidak bagi kemaslahatan hamba tersebut. Kemaslahatan hamba inilah yang menjadi suatu tujuan akhir diciptakan suatu undang-
${ }^{[12]}$ Ibid, 86.

[13] Ibid, 87. 
undang. Sebab jika terdapat suatu kejadian yang tidak ada nasnya, tetapi illatnya serasi dengan illat dalam suatu kejadian yang telah terdapat nasnya dan didduga keras bisa memberikan kemaslahatan untuk hamba, bahwa adillah jika ia disamakan hukumnya dengan kejadian yang telah terdapat nas itu hanya merealisir kemaslahatan yang dicita-citakan oleh undangundang.

2) Nash al-Qur'an serta Sunnah bisa dikatakan terbatas. lalu peristiwa pada manusia itu tidaklah terbatas dan tidak pula berakhir. Oleh sebab itu tidak mungkin nash yang terbatas tersebut dijadikan sumber terhadap kejadian tidak terbatas. Dengan demikian qiyas merupakan sumber perundang-undangan yang dapat mengikuti kejadiankejadian baru dan dapat menyesuaikan dengan kemaslahatan.

\section{Macam Qiyas}

Qiyas dibagi menjadi 5 (empat) macam, antara lain :

a. Qiyas Aula, merupakan bentuk qiyas yang illat-nya mewajibkan hukum itu ada dan disamakan (mulhaq) serta memiliki hukum yang lebih diutamakan selain tempat menyamakannya (mulhaqbih). ${ }^{14}$ Seperti halnya, mengqiyaskan mengatakan ah dengan kedua orang tua dengan memukul kedua orang tua, yang disebutkan dalam firman Allah :

${ }^{14}$ Agus Miswanto, "Ushul Fiqh Metode Ijtihad Hukum Islam Jilid 2",(Yogyakarta : Magnum Pustaka Utama, 2018). 127.

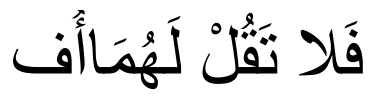

Artinya:

"...janganlah kamu mengatakan "ah" kepada kedua orang tua ..." megucapkan "ah" kepada kedua orang tua itu sangatlah dilarang sebab illat-nya ialah menyakiti hati. Maka dengan hal tersebut, memukul kedua orang tua itu tentu lebih dilarang, karena di samping yang paling utama menyakiti hati mereka juga bisa menyakiti jasmani mereka. Illat yang di larangan dalam Muhaq (secara analogis) lebih berat daripada di Muhaq. Oleh karena itu, melarang tamparan pada orang tua Anda lebih ketat daripada melarang mengatakan "ah" padanya. ${ }^{15}$

b. Qiyas Musawi ialah salah satu bentuk qiyas, dan illatnya harus ada hukumnya, dan hukum illat yang terkandung dalam mulhaq sama dengan hukum illat dalam mulhaq bih. ${ }^{16}$ Misalnya :

"dan berikanlah kepada anakanak yatim (yang sudah balig) harta mereka, jangan kamu menukar yang baik dengan yang buruk dan jangan kamu Makan harta mereka bersama hartamu. Sesungguhnya tindakantindakan (menukar dan memakan) itu, adalah dosa yang besar."(QS alNisa : 2).

Dalam ayat tersebut menjelaskan bahwa menghancurkan harta benda yatim piatu memiliki efek hukum yang sama dengan melahap harta yatim piatu, yaitu merusak harta benda. Pada saat yang sama, mereka

\footnotetext{
15 Team KPI, "Modul Ushul Fiqh" (Mojokerto : Institut Pesantren K.H. Abdul Chalim Press, 2019), 192 .

${ }^{16}$ Agus Miswanto, "Ushul Fiqh Metode Ijtihad Hukum Islam Jilid 2"......127.
} 
yang memakan harta anak yatim piatu dilarang. ${ }^{17}$

c. Qiyas Al-Adwan, ialah Qiyas Qiyas yang illat hukum yang terselip pada mulhaq (yang dibanding) lebih rendah ketimbang dengan illat hukum yang terdapat pada mulhaq bih( pembanding) :

"Hai orang-orang yang beriman, bertakwalah kepada Allah dan tinggalkan sisa Riba (yang belum dipungut) jika kamu orang-orang yang beriman." (QS al-baqarah : 278).

Dalam ayat di atas dipaparkan tentang perintah kepada orangorang yang beriman buat meninggalkan praktek riba. Riba dalam hadis Nabi terdapat 2 tipe ialah riba yad (pertukaran langsung) dan nasia'ah (hutang). Riba nasiah dengan bunga kerap disbanding atau dipersamakan. Cuma saja illat yang terdapat dibunga bank itu lebih rendah dibanding dengan praktek riba era dulu. $^{18}$

d. Qiyas Dilalah ialah qiyas dimana illat yang terdapat pada mulhaq/ yang disamakan, Menunjukkan hukum, akan tetapi hukumnya tidak wajib. ${ }^{19}$ Misal, illat yang diqiyaskan adalah segala harta benda dan harta benda yang dapat ditingkatkan Ciri khas barang bawaan Harta anak dan harta orang dewasa serta wajib mengeluarkan zakat. Dalam hal ini, Abu Hanifah (Abu Hanifah) berpandangan lain bahwa harta benda dan harta benda anak di bawah umur tidak wajib untuk membayar zakat / dizakati, karena dilakukan

\footnotetext{
17 Team KPI, "Modul Ushul Fiqh"....194.

18 Agus Miswanto, "Ushul Fiqh Metode Ijtihad Hukum Islam Jilid 2".....128.

${ }^{19}$ Ibid, 129
}

melalui ibadah haji karena yang bersangkutan masih belum dianggap dewasa (mukalaf).

e. Qiyas Syibhi, ialah wujud qiyas yang mulhaqnya dapat diqiyaskan ke dua mulhaq bih, hendak namun mulhaq bih yang memiliki banyak kesamaan dengan mulhaq yang bisa diqiyaskan. Semacam, seseorang hamba sahaya yang sudah dirusak oleh seorang. Budak yang sudah dirusak dapat diqiyaskan (disamakan) dengan orang yang merdeka karena kedua perihal tersebut ialah dapat dikatakan bersama generasi dari adam serta dapat pula disamakan dengan harga serta barang, karena keduanya bersama mempunyai. Hendak namun, budak itu bisa diqiyaskan dengan harta serta barang, ialah bersama dapat diperjualbelikan, diwariskan, dihadiahkan serta sebagainya. Sebab hamba sahaya itu disamakan dengan harta barang, serta yang dirusakkan tersebut dapat ditukar dengan nilai. ${ }^{20}$

\section{HASIL DAN PEMBAHASAN}

\section{Pengertian Mudharabah}

Mudharabah berasal dari bahasa arab yang artinya "bagi hasil, dan bisa semakna dengan Al-Qath 'u yaitu potongan atau bepergian. Diterangkan pada surah Al-Muzammil : 20,

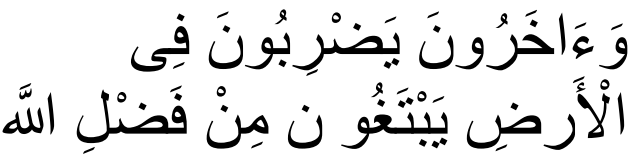

Artinya :

"dan yang lainnya, bepergian di muka bumi mencari karunia Allah"

Dalam ayat tersebut diterangkan istilah mudharabah secara langsung, tetapi melewati akar kata darb yang di jelaskan sebanyak 58 kali. Dari kata tersebut lalu munculah kata mudharabah.

20 Team KPI, "Modul Ushul Figh".....194. 
Mudharabah berdasarkan dari pendapat Sayid Sabiq mendefinisikan bahwa mudharabah ialah bentuk akad yang dimana dari kedua pihak dari salah satunya memberikan modal kepada pihak yang lainnya (pengelola/pemberi tenaga) untuk di perjualbelikan dengan ketetapan yaitu keuntungan dibagi dua sesuai dengan kesepakatan diawal akad.

Maka dari pendapat dari sayid sabiq dapat di pahami bahwa Pengertian dari mudharah yaitu suatu perjanjian kerja sama antara shahibul maal (pemberi modal) dengan mudharib (pengelola dana) atau juga bisa dikatakan sebagai pihak pemberi tenaga dan keahliannya dalam menjalankan usahanya, lalu keuntungan dari usaha secara mudharabah akan dibagi sesuai dengan akad perjanjian di awal kontrak.

2. Syarat dan Dasar Hukum Mudharabah

Terdapat beberapa syarat dan rukun sah dari mudharabah diantaranya yaitu :

a. Barang dan modal yang diberikan harus dalam bentuk uang tunai. Jika barang tersebut adalah emas dan perak maka akad dari mudharabah itu sendiri batal.

b. Modal yang di gunakan harus jelas, agar bisa dibedakan mana yang laba dan modal usaha. Karena laba tersebut yang akan dibagi sesuai dengan perjanjian kontrak yang disepakati.

c. Untuk seseorang yang ber akad, disyaratkan untuk mampu melakukan tafsharruf, yang dimana akad dilaksanakan untuk anak kecil, orang gila serta orang dibawah kekuasaan orang lain, maka akad mudharabah dibatalkan.

d. Dalam pembagian keuntungan antara pemberi modal dan pelaksana harus jelas dan sesuai dengan akad yang dijanjikan dari awal.

e. Adanya ijab dan qabul.

Adapun rukun yang harus dilaksanakan dalam ber akad mudharabah menurut ulama Syafi iyah diantaranya rukun qiradh ada enam :

a. Pemodal harus menyerahkan barang-barangnya kepada penerima modal.

b. Bagi yang bekerja, pengelola yang menerima barang.

c. Akad mudharabah, dilaksanakan / dikerjakan oleh pemilik barang dan pengelola.

d. Adanya maal (harta pokok dan modal)

e. Amal, (proyek pengelola yang menghasilkan keuntungan)

f. Laba/keuntungan.

Adapun beberapa dasar hukum dari akad mudharabah sebagai berikut :

"apabila telah ditunaikan shalat, Maka bertebaranlah kamu di muka bumi; dan carilah karunia Allah dan ingatlah Allah banyak-banyak supaya kamu beruntung." (Surat Al-Jumu'ah : 10)

Terdapat pula hadits mengenai mudharabah yaitu pada hadits dari riwayat Ibnu Majjah dari Shuhaib, Rasulullah SAW bersabda :

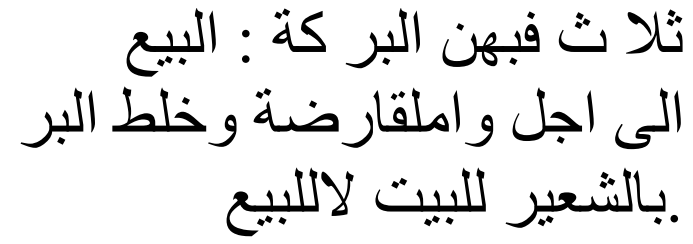

Artinya :

"tiga perkara yang mengandung berkah ialah jual beli yang ditangguhkan, mengerjakan qiradh (memberi modal kepada orang lain), dan yang mencapurkan gandum dengan jelas untuk keluarga, bukan untuk 
diperjualbelikan."(HR. Ibnu Majjah dari Shuhaib) ${ }^{21}$

\section{Konsep Mudharabah dalam fiqh}

Madzha Hanafi, menerangkan bahwa akad mudharabah boleh dilakukan dikarenakan orang memerlukan akad mudharabah dalam bertransaksi usaha, lalu pada madzhab maliki beranggapan bahwa dibolehkannya sebagai kelonggaran yang khusus. Walaupun didalam AlQuran dan Sunnah tidak diterangkan akad mudharabah secara langsung akan tetapi praktik mudharabah ini diakui oleh umat Islam dari bentuk usaha maupun di lembaga keuangan.

Dalam akad mudharabah harus jelas jumlah modalnya, karena ini dapat dilihat apabila jumlah modal dinyatakan dalam satuan mata uang dan modal yang diberikan tidak boleh dari satuan hutang yang dipinjamkan kepada mudharib saat berlangsungnya kontrak dari akad mudharabah itu sendiri. Lalu didalam kontrak mudharabah tidak diperbolehkan terdapat syarat yang sudah ditetapkan jangka waktu tertentu bagi kongsi. Karena syarat ini bisa mengakibatkan kontrak dari perjanjian itu batal, demikian menurut mazhab Syafii dan Maliki.

Dalam kontrak mudharabah terdapat suku laba bagi tiap pihak. Maksud dari penetapan tertentu yaitu misalkan satu juta satuan mata uang, untuk salah satu pihak ingin membatalkan akad mudharabah dikarenakan terdapat kemungkinan karena keuntungan tidak tercapai jumlah yang sudah ditetapkan dari perjanjian awal. Maka sebelum mendapatkan laba, kongsi dari

${ }^{21}$ Akhmad Farroh Hasan, "Fiqh Muammalah Dari Klasik Hingga Kontemporer (Teori Dan Praktek)",(Malang : UIN Maliki Press, 2018), 108. mudharabah harus menjadi modal dan uang harus disisihkan dan mudharib tidak diizinkan untuk mengikat kongsi mudharabah dengan jumlah yang melebihi dari modal. ${ }^{22}$

Dalam transaksi bermuamalah, melakukan akad mudharabah adalah diperbolehkan (mubah). Karena hal ini terdapat didalam hadits nabi yang diriwayatkan Ibnu Majah dari Shuhaib r.a Rasul bersabda :

"ada tiga perkara yang diberkati : jual beli yang ditangguhkan, memberi modal, dan mencampur gandum dengan jelai untuk keluarga, bukan untuk dijual"

Dari hadits Rasul diatas maka sudah pasti transaksi muamalah dalam akad mudharabah sangat boleh dilakukan dan harus dilakukan sesuai dengan syariat Islam. ${ }^{23}$

\section{Qiyas Mudharabah Terhadap Musaqah}

Bentuk penerapan dari sumber hukum Islam pada akad mudharabah yang sesuai dengan menggunakan ushul fiqh yaitu AlQiyas. Al-Qiyas merupakan sebuah usaha dalam mengkategorikan suatu cabang (makna) untuk makna lain (pokok), sebab makna dari cabang tersebut terdapat kesamaan dengan makna pokok, setelah itu di proyeksikan baik dari sifatnya ('illat) hukum cabang itu lebih serupa atau utama.

Dalam akad Mudharabah bisa diqiyaskan pada akad Al-Musaqah yaitu bentuk kerja sama antara pemilik kebun dengan penggarap kebun yang dimana pemilik kebun memberikan/menyerahkan ke penggarap kebun untuk dirawat, dan

\footnotetext{
${ }^{22}$ Mahmudatus Sa diyah dan Meuthiya Athifa Arifin, "Mudharabah Dalam Fiqih dan Perbankan Syari'ah", Jurnal Hukum Ekonomi Syariah, IAIN Kudus Vol. 1, No 2, (2013), 315.

${ }^{23}$ Rahman Ambo Masse, "Konsep Mudharabah Antara Kajian Fiqh dan Penerapan Perbankan", Jurnal Hukum Diktum, STAIN Parepare Vol.8, No.1 (2010), 79.
} 
keuntungannya sudah dijanjikan diawal akad perjanjian. Maka disini bisa dilihat bahwa kesamaan illat antara mudharabah dan musaqah yaitu sama-sama bentuk kerja sama antara pemilik modal/kebun dengan pengelola. Adapun dari syara musaqah yaitu memberikan pada orang yang merawat dan menjanjikan jika pohon yang diberikan untuk dirawatnya sudah untuk siap panen dan diambilah dari manfaat sebagai sebagian imbalan dari pengelolaan. Maka hal tersebut bisa diqiyaskan dengan contoh dari akad mudharabah akan tetapi objek yang diberikan yaitu dalam bentuk uang/modal yang diberikan kepada mudharib untuk mengelola usaha dan keuntungan yang diberikan dalam bentuk uang. Maka bisa disimpulkan bahwa Mudharabah adalah suatu akad yang diaplikasikan kedalam bentuk usaha serta modal yang diberikan dalam bentuk uang, akad mudharabah sering digunakan juga di dalam lembaga keuangan yang berbasis syariah. Lalu jika Musaqah yaitu modal yang diberikan yaitu adalah sebuah kebun kepada pengelola untuk merawatnya dan musaqah sering di gunakan dalam bentuk pertanian.

Adapun terdapat ayat Al-Quran yang menerangkan hukum Musaqah adalah pada surah Al-Maidah ayat 2, yaitu :

"dan tolong-menolonglah kamu dalam (mengerjakan) kebajikan dan takwa, dan jangan tolong-menolong dalam berbuat dosa dan pelanggaran. dan bertakwalah kamu kepada Allah, Sesungguhnya Allah Amat berat siksa-Nya."'(Surat Al-Maidah : 2).

Ayat tersebut menerangkan bahwa Allah telah memerintahkan untuk saling tolong-menolong dalam kebaikan dan meninggalkan perilaku yang buruk yang bisa mengakibatkan kemudharatan bagi diri pribadi dan orang lain. ${ }^{[2]}$ Dasar hukum ini

\footnotetext{
${ }^{24}$ Shania Verra Nita, "Kajian Muzara'ah dan Musaqah (Hukum Bagi Hasil Pertanian Dalam
}

juga dapat dijadikan sebagai landasan hukum untuk akad Mudharabah sebab didalam akad mudharabah juga menyertakan untuk berbuat tolong menolong serta mencari karunia dan pahala dari Allah SWT, diterangkan dalam penggalan Q.S. AlMuzammil ayat 10 :

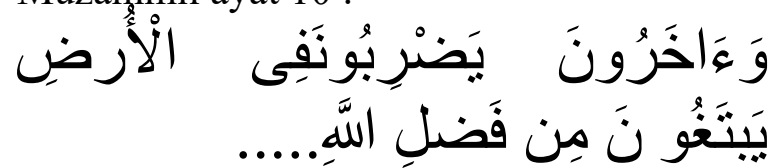

Artinya :

"dan orang-orang yang berjalan di muka bumi mencari sebagian karunia Allah"

Ayat ini menjelaskan bahwa sebagai orang mukmin yang hidup, Maka mungkin selalu mencari Rezeki (anugrah Tuhan) serta mencari karunia Allah dengan Bermuamalah, Salah satunya adalah kerjasama antar manusia. Dalam Alquran, termasuk ayatayat di atas, tidak ada apa-apa Menerapkan Mudharabah, tetapi dari berbagai ayat AlQuran tentang Muamalah, Kesimpulannya adalah memungkinkan kerjasama dengan mudharabah. ${ }^{25}$

Dalam didalam Al-Quran sudah diterangkan dengan jelas bahwa, dalam bermuamalah hendaknya untuk bekerjasama dengan cara tertulis baik dalam akad mudharabah dan musaqah, seperti halnya diterangkan dalam Q.S Al-Baqarah ayat 282 :

"Hai orang-orang yang beriman, apabila kamu bermu'amalah tidak secara tunai untuk waktu yang ditentukan, hendaklah kamu menuliskannya. dan hendaklah seorang penulis di antara kamu menuliskannya dengan benar..."(Surat AlBaqarah : 282).

Islam) The Muzara'ah dan Musaqah Study (Agricultural Production Sharing Law In Islam)", jurnal Qawain, IAIN Ponorogo. Vol.8, No.1, (2010), 241-242.

25 Mahmudatus Sa'diyah dan Meuthiya Athifa Arifin, "Mudharabah Dalam Fiqih dan Perbankan Syari'ah", .....315. 
Adapun kesamaan illah dari mudharabah dan musaqah yaitu pada syarat serta berakhirnya musaqah. Kesamaan tersebut berupa syarat pertama dari mudharabah yaitu adanya sighat (adanya ijab dan qabul) ${ }^{26}$, lalu di dalam syarat musaqah juga terdapat istilah sighat dan untuk syarat yang kedua sama-sama harus berakal serta baligh dalam bekerja sama ${ }^{27}$, namun dari sisi objek akadnya terdapat perbedaan jika objek akad yang digunakan dalam mudharabah adalah uang maka untuk musaqah berupa kebun atau pohon yang mempunyai manfaat untuk pemilik dan pengelola. Dalam syarat pembagian keuntungan objek dalam bagi hasil juga berbeda, untuk keuntungan ${ }^{28}$ yang diberikan dari akad mudharabah keuntungan yang diberikan berupa uang dan untuk musaqah berupa hasil panen yang dimana dibagi sesuai perjanjian. ${ }^{29}$

maka dapat disimpulkan dari penjelasan diatas bahwa syarat yang digunakan terdapat kesamaan illat akan tetapi objek yang diberikan dalam kedua akad tersebut berbeda namun dalam satu illat yang sama. Dan dalam syarat berakhirnya kedua akad tersebut terdapat point-point yang memiliki kesamaan dan perbedaan diantara kesamaan itu adalah adanya salah satu dari kedua belah pihak yang meninggal maka akad tersebut batal, terdapat suatu hal yang bisa menghalangi masing-masing pihak dan tidak bisa meneruskan kesepakatan ${ }^{30}$ maka bisa

${ }^{26}$ Ibid, 309.

${ }^{27}$ Akhmad Farroh Hasan, "Fiqh Muammalah Dari Klasik Hingga Kontemporer (Teori Dan Praktek)",...101.

${ }^{28}$ Rahman Ambo Masse, "Konsep Mudharabah Antara Kajian Fiqh dan Penerapan Perbankan",...79.

${ }^{29}$ Shania Verra Nita, "Kajian Muzarrah dan Musaqah (Hukum Bagi Hasil Pertanian Dalam Islam)", Jurnal Qawain, IAIN Ponorogo, Vol.4, No.2, 2020, 243.

${ }^{30}$ Mahmudatus Sa diyah dan Meuthiya Athifa Arifin, "Mudharabah Dalam Fiqih dan Perbankan Syari'ah", .....313. dianalogikan seperti salah satu dari kedua belah pihak ada yang murtad atau gila maka hal tersebut bisa menghalagi akad dan menjadi berakhir. Selain itu adalah perbedaan-perbedaan dari akad mudharabah dan musaqah.

Karena berdasarkan dalam konsep qiyas, maka dalam praktik akad Mudharabah adalah sebagai ashl lalu Al-Musaqah adalah sebagai far'u, setelah itu keduanya disatukan ke dalam illat yang sama ialah kerja sama antara pemilik modal/kebun terhadap pengelola/pemberi tenaga dalam menjalankan usaha lalu dalam pembagian keuntungannya sudah disepakati di awal akad perjanjian. Maka dengan ini, mudharabah dan musaqah di perbolehkan dalam kegiatan usaha.

\section{KESIMPULAN}

Kesimpulan dari pembahasan diatas ialah qiyas adalah mempersamakan illah yang ada pada furu' dengan illah yang ada pada ashal yang diistinbatkan dari hukum ashal. Qiyas mempunyai 4 syarat sah dalam pengqiyasan suatu peristiwa diantaranya ashal, cabang, dalam hukum far'u dan illah. Jika dalam penqiyasan suatu peristiwa tidak sesuai dengan syarat dan rukun qiyas maka hal tersebut belum bisa diqiyaskan. Lalu qiyas pada akad mudharabah yaitu musaqah (menyuruh seseorang dalam mengelola kebun). Kesamaan illah pada akad mudharabah dan musaqah adalah sama-sama menyerahkan suatu modal (dalam bentuk uang/kebun) untuk dikekola oleh pengelola/mudharib, dan terdapat pula kesamaan illat dari syarat mudharabah dan musaqah namun terdapat poin yang berbeda tetapi bermakna sama.

Karena berdasarkan dalam konsep qiyas, maka dalam praktik akad Mudharabah adalah sebagai ashl lalu Al-Musaqah adalah sebagai far'u, setelah itu keduanya disatukan ke dalam illat yang sama ialah kerja sama antara pemilik modal/kebun terhadap 
pengelola dan dalam keuntungannya sudah disepakati di awal akad. Maka dengan ini, mudharabah dan musaqah di perbolehkan dalam kegiatan usaha.

\section{REFERENSI}

[1] Andi Ahriana Astuti Bahar, 2020, "Tinjauan Hukum Islam Terhadap Pembelian Barang Koleksi di Kelurahan Tamarunang Kecamatan Somba Opu Kabupaten Gowa (Studi Perbandingan Imam Abu Hanifa dan Imam Syafi 'i)", Universitas Islam Negeri Alauddin, Vol. 1, No. 3.

[2] Azhari Fathurrahman, 2013, "Qiyas Sebuah Metode Penggalian Hukum Islam", Jurnal Hukum dan Pemikiran, UIN Antasari, Vol 13, No 1.

[3] Fuad Ahmad Masfuful, 2016, "Qiyas Sebagai Salah Satu Metode Istinbāt Al-Hukm", UIN Sunan Kali Jaga, Mazahib,Vo.l, No.1.

[4] Darmawan H, 2020, "Ushul Fiqh", Surabaya : Revka Prima Media.

[5] Haika Ratu, 2012, "Konsep Qiyas Dan Ad Dalil Dalam Istinbat Hukum Ibn Hazm", STAIN Samarinda, Fenomena, vol.4, No.1.

[6] Hasan Akhmad Farroh, 2018, "Fiqh Muammalah Dari Klasik Hingga Kontemporer (Teori Dan Praktek)", Malang : UIN Maliki Press.

[7] Masse Rahman Ambo, 2010, "Konsep Mudharabah Antara Kajian Fiqh dan Penerapan Perbankan", Jurnal Hukum Diktum, STAIN Parepare Vol.8, No.1.

[8] Miswanto Agus, 2018, "Ushul Fiqh Metode Ijtihad Hukum Islam Jilid 2",(Yogyakarta : Magnum Pustaka Utama.

[9] Nita Shania Verra, 2020, "Kajian Muzarrah dan Musaqah (Hukum Bagi Hasil Pertanian Dalam Islam)", Jurnal Qawain, IAIN Ponorogo, Vol.4, No.2.

[10] Purnamawati Anni Muslimah, 2017, "Konsep Qiyas dalam Transaksi Ekonomi Money Changer", , Jurnal Ekonomi Islam dan Sosial, Sekolah Tinggi Agama Islam Negeri Pamekasan, Volume 1. Nomor 1.

[11] Syafii Rahmat, 2010, "ilmu Ushul Figh", Bandung: Pustaka Setia. [12] Sa'diyah Mahmudatus dan Arifin Meuthiya Athifa, 2013, "Mudharabah Dalam Fiqih dan Perbankan Syari'ah", Jurnal Hukum Ekonomi Syariah, IAIN Kudus Vol. 1, No 2.

[13] Team KPI, 2019, "Modul Ushul Fiqh" Mojokerto : Institut Pesantren K.H. Abdul Chalim Press. 